\title{
THE PARADIGM OF PLURAL ISLAMIC THEOLOGY IN INDONESIA
}

\author{
Sirajuddin M.* \\ Moh. Dahlan** \\ State Islamic Institute (IAIN) Bengkulu \\ *Email: sirajuddin.bkl@gmail.com, \\ **Email: drdahlan@yahoo.co.id
}

\begin{abstract}
Indonesia's plural society requires the formulation and relationships of life that are not taken for granted, but must be inclusive, progressive and pluralistic. If there is no scientific paradigm with its plural character, then there will be attitude that tends to be repressive or al-tatarruf (extreme). The repressive act or the imposition of theological understanding will lead to destruction or conflict. Therefore, this study is formulated as: How paradigm of Islamic theology study can be built in accordance with the interests of its era? How to build a pattern of ideal relationship between the religions in a plural country like Indonesia? Results of this study is that the approach of Islamic theology study will be able to encourage the emergence of paradigm of Islamic study and paradigm on pattern of inter-religion relationship to build paradigm of plural Islamic theology, patterns of relationships and sincere inter-religion cooperation, namely de jure pluralism (being religious), not as de facto pluralism (having religious).
\end{abstract}

Keywords: Paradigm, Islamic theology, plurality, interreligious relations.

DOI: http://dx.doi.org/10.20414/ujis.v19i2.33 


\section{Introduction}

THE EXISTENCE of Indonesia's society with its plural character in the form religion, faith group, language, culture, and race requires flexible and simple scientific discourse. According to Azyumardi Azra, Indonesia's plural society needs formulation and relation of life that is not taken for granted but they have to be developed systematically, progressively and sustainably. One of the important factors in pluralism is plural religious which requires flexible and simple scientific discourse ${ }^{1}$. If there is no scientific paradigm with pluralism, then there will be monolithic or exclusive paradigm that tends to be repressive or al-tatarruf (extreme). In this case, the repressive act or the imposition of theological understanding will lead to destruction or conflict ${ }^{2}$. Indonesia's society currently face big challenge, according to Sri Hartati Samhadi, Indonesia has been not planning anything and any roles in the future. If Indonesia is not able to play any roles soon in the era of globalization, especially in economic sector, it will be sunk. It seems that doubt comes to Indonesia in facing this era, as Indonesia is under pressure of nationalism sentiment inside. According to executive director of Center for Strategic and International Studies (CSIS), Hadi Soesastro, government policy in facing globalization is not laid down on ideological consideration, but focus on objective assessment to what can be achieved in other East Asia countries. ${ }^{3}$

${ }^{1}$ Gustiana Isya Marjani, "Multikulturalisme dan Pendidikan: Relevansi Pendidikan dalam Membangun Wacana Multikulturalisme di Indonesia", paper presented at ACIS Diktis Depag RI, 2009, 4.

In the context of impositioning modernism ideology in Islamic religious, Karen Amstrong mentioned the case of Turkey, that the real paradigm of Islamic theology requires a change and dialogue between the civilization to get ahead, not based on impositioning as the case of Mustafa Kemal policy who did cultural westernization. Karen Amstrong, Sejarah Tuhan, translated by Zaimul Am, (Bandung: Mizan, 2001), 464-465.

${ }^{3}$ This is different to China and India that have prepared themselves and been playing important roles in globalization. China turns to be the world's factory and India becomes IT outsourcing, both countries are racing for being world innovation epicentrum, manufacture hub, or other missions. China and India, with their expansion based on current parameter and upcoming prediction, will win the open battle in which everything is borderless not only information, capital, service, and people but also 
In this context, globalization can bring more harms if it could not be treated properly like a case of the first economic package policy in 1986-1990 issued by Indonesia's government. The policy covered at least 20 packages of investment and trading liberalization but the policy which aims to support private sector tends to be reactive, incoherent and discriminative. It was called so since certain group or sector of deregulation program were not included. ${ }^{4}$

The uncertain condition in economic sector, if it is not anticipated, will affect nation's ideology or religious which has been setting as foundation in developing the unitary state of the republic of Indonesia (NKRI). Meanwhile, NKRI was built on the awareness of nationality with its religious character. The building block of this republic will be fragile if its nationality insight and religious are weak. In addition, the common enemy of Indonesia now is not gunman anymore, but long term poverty which can kill and affect nation's ideology or religious. To answer the question, we need to build theology construct which leaves away from narrow, exclusive, and close religious insight. There are 2 potential things that hamper the development of nation's theology; the only truth one belongs to certain religion (truth-claim) and overdose attitude in religion, which leads to easily judge or blame others ${ }^{5}$.

In this case, the development of the paradigm of Islamic theology discourse should be put in special attention and out from the trap of exclusive or overdose paradigm of theology (altatarruf) since Indonesia's diverse condition especially in religion requires flexible and plural as character of nation in all its

ideology and nationalism. In economic sector, China and India have upgraded their industry in sweat-shop however Indonesia has not. Sri Hartati Samhadi, "Globalisasi dan Indonesia 2030" in Chris Verdiansyah (ed), Membongkear Budaya: Visi Indonesia 2030 dan Tantangan Menuju Raksasa Dunia, (Jakarta: Kompas, 2007), 12-13.

"Samhadi, "Globalisasi dan Indonesia 2030" dalam Chris Verdiansyah (ed), Membongkar Budaya, 12-13.
${ }^{5}$ Yonky
Karman,
Teologi
Kebangsaan, http: / / www.unisosdem.org/article_detail.php?aid=10089\&coid=3\&caid =3 1 \&gid=2, accessed at 29 October 2015 . 
sectors $^{6}$. That is very important since religious category has its own plural paradigm. It will cause conflict if this flexible and plural paradigm cannot be followed. On the other word, Indonesia which is characterized by its pluralistic especially in religion aspect does require flexible, plural, and simple paradigm of religious ${ }^{7}$.

According to M Amin Abdullah, basic problem faced by Indonesia is dichotomy in religious paradigm, i.e. doctrinaldogmatic or empiric-positivistic. This religious paradigm has formed conflict in religious, either in the level of conceptual or practices. That is why pluralism problem in religious should be answered a pattern of life which is able to create conducive condition amongst different religions. A proper paradigm is plural paradigm of Islamic theology as a choice in Indonesia's plural society ${ }^{8}$.

Regarding this, we formulate a study: How paradigm of Islamic theology study can be built based on interest of its era? How to build an ideal pattern of life amongst religions in Indonesia's plural nation? This study aims to address the issue of Islamic theology built to meet its era and build ideal pattern of life amongst religions in Indonesia's plural condition.

\section{Theoretical Framework}

This study applies philosophy approach which describes the problem of paradigm of plural Islamic theology based on rational analysis, i.e. First, place people mind as a fundamental part in the reflection of experience and religious faith in a religious tradition. Part of religious reflection is studying

'UUD 1945 dan Amandemennya, (Surakarta: Al-Hikmah), 10. 42.

${ }^{7}$ M. Amin Abdullah, Studi Agama; Normativitas dan Historisitas (Yogyakarta: Pustaka Pelajar,1996), 5.

${ }^{8}$ Abdullah, Studi Agama, 7. Nurcholish Madjid, "Keharusan Pembaruan Pemikiran Islam dan Penyegaran Kembali Pemahaman Keagamaan", in Charles Kurzman (ed.), Wacana Islam Liberal: Pemikiran Islam Kontemporer tentang Isu-Isu Global, translated by. Bahrul Ulum, (Jakarta: Paramadina, 2001), 485; Greg Barton, Gagasan Islam Liberal di Indonesia; Pemikiran NeoModernisme Nurcholish Madjid, Djohan Efendi, Ahmad Wabib, dan Abdurrahman Wahid, translated by. Nanang Tahqiq, Jakarta: Pramadina, Pustaka Antara, dan The Ford Foundation, 1999), 3. 
thoroughly about religious doctrines, symbols, and models used in tradition. Second, in describing faith or theology, mind should be used in producing logical arguments and reasonable claims 9

To study the paradigm of plural Islamic theology, the work of Edward Scillebeeckxis a good read, i.e. pluralisme de jure. It builds scientific paradigm and a pattern of inter-religion relation which does not exist for a compulsion but for sincerity and willingness (read: de jure pluralism). This is not similar to de facto pluralism in which scientific paradigm and pattern of interreligion relation are not sincere and pure ${ }^{10}$.

\section{The Concept of Islamic Theology}

In paradigm of Islamic studies, Islamic theology has some terminologies: First, theology ('ilm al-kalam) is rational theology which presents for the sake of defending certain thought group ${ }^{11}$. It firstly existed in the era of caliph al-Ma'mūn (Ibn Harun al-Rashid, 813-833 M). A problem which affects its presence is about 'speaking' as one of God's character. Second, monotheism ${ }^{12}$, well known as ilm al-Tauhid, is teaching about the aim of knowledge, i.e. God is only one. Third, uṣul al-din is about the basic of Islam ${ }^{13}$.

Fourth, according to Frank Whaling, there are 3 views on theology, i.e. (a) knowledge relates to God or trancendention, it can be mythology, philosophy or dogmatic; (b) although doctrine has many forms, it still becomes significant element to

${ }^{9}$ Rob Fisher, "Pendekatan Filosofis", in Peter Connolly (ed), Aneka Pendekatan Studi Agama, translated by. Imam Khoiri, (Yogyakarta: LKiS, $1999), 155$.

${ }^{10}$ Haryatmoko, "Pluralisme De Jure, Kritik Ideologi", in M. Amin Abdullah et al, (eds.), Antologi Studi Islam, (Yogyakarta: DIP PTA IAIN Sunan Kalijaga, 2000), 38.

${ }^{11}$ TIM Yayasan Paramadina, Al-Ghazali tentang Ilmu Kalam, (Jakarta: Yayasan Wakaf Paramadina, 1995), 9; A. Athaillah, Rasyid Ridha': Konsep Teologi Rasional dalam T afsir al-Manar, (Jakarta: Erlangga, 2006), 9-10.

${ }^{12}$ Athaillah, Rasyid Ridha, 9.

13Paramadina, Al-Ghazali tentang, 9. 
understand theology; (c) the real theology is the activity which comes from faith or the interpretation of faith ${ }^{14}$.

Fifth, according to Harun Nasution, theology (ilm al-kalām) can be called as "Islamic theology" since its main topic is about the existence of God, men's relation to God such as faith, unfaith, men's action, the act and character of God. On the other word, the main topic of theology is about believe in God $^{15}$, it is knowledge which strengthen faith in religion with rational thinking, or a wider definition is that knowledge which explain about believing God and answering those who refuse with rational thinking ${ }^{16}$.

\section{The Paradigm of Islamic Theology Studies: From Exclusive to Pluralism}

Islamic theology taught by Prophet Muhammad does not call off the messages and perceptions of prior prophets totally, but it provides space for the continuation of theology experiences or religious of prior mankind. Islamic theology does not reproach other tradition of religious theology as an incorrect and incomplete, but it shows that every new prophet always support and continue teachings of prior prophets. ${ }^{17}$ Thus, the principle of Islamic theology underlines the importance of inclusivity and pluralism by putting other religions into equal position. One year before leaving for Madinah (Hijra), Prophet Muhammad has adapted Islamic theology to the teaching of Judaism. Islamic theology also teaches similar faith as prior prophets did such as fasting, Muslim man can marry Jews and Christian woman. ${ }^{18}$

${ }^{14}$ Frank Whaling, "Pendekatan Teologis", in Connolly (eds.), Aneka Pendekatan, 31.

${ }^{15}$ Harun Nasution, "Sejarah Pertumbuhan Ilmu Kalam" in Saiful Muzani (eds.), Islam Rasional: Gagasan dan Pemikiran Prof Dr Harun Nasution, (Bandung: Mizan, 1995), 368.

16Athaillah, Rasyid Ridha..., 9-10.

${ }^{17}$ Amstrong, Sejarah Tuhan, 205, 207, dan 211; readhttp://muisulsel.org/index.php?option $=$ com_content\&view $=$ article\&id $=132$ : sejarahawal-penggunaan-metode-halaqah\&catid $=69$ :drs-h-waspada-santing-msosimhi\&Itemid $=187$

${ }^{18}$ Amstrong, Sejarah Tuhan, 212-213 dan 2018. 
The history of Islamic theology experienced unique dynamics and the first problem existed in theology was starting from political conflict then reach theological problem. This political conflict contributed to the emergence of school of theology like Muktazila, Aș'ariya, Khawāriz, and Shi'a. Even though the problem came to the surface, Islamic theology discourse ever reached top position when Muktazila theology was officially practiced as state school in the era of caliph alMa'mūn. The caliph supported Muktazila and made its discourse as official doctrine of Muslim people. Further, he forced other Islamic theology groups like traditionalist. He even did repressive action if people refused the discourse. ${ }^{19}$

That kind of unhealthy and extreme theology has caused a setback for Muslim since it did not refer to the real Islamic theology. Jamāl al-din al-Afghāni stated that Islamic values are not the factor which influence setback of Muslim but the problem is their disobedience toward the real Islamic theology. They also followed strange religious theology. The other factor is political disunity, i.e. absolute government, a leader who betrays people's will, incompetent leader and intervention from other sides. In this case, Jamāl al-din al-Afghāni stated that the way to improve Muslim condition is returning to the real Islamic theology while strange religious theology is omitted. ${ }^{20}$

Muhammad Abduh has same idea with Jamāl al-din alAfghāni regarding the factors which cause setback of Muslim, he stated that old paradigm of Islamic theology concept, i.e. frozen condition, static, and no changes. Muslim has not changed yet and accepted change since old Islamic theology concept influences them. Muslim has been keeping a certain tradition which possibly does not meet the progress of current era and its condition. Strange Islamic teachings come into Islamic theology and make Muslim forget their real Islamic theology teachings. For this reason, Abduh attempted to revise Islamic theology to meet the progress of current era, by reinterpreting and opening

${ }^{19}$ Ibid., 227; Ira M Lapidus, Sejarah Sosial Ummat Islam, translated by Ghufron A Mas'adi, (Jakarta: Raja Grafindo Persada, 1999), 159.

${ }^{20}$ Harun Nasution, Pembaruan dalam Islam: Sejarah Pemikiran dan Gerakan, (Jakarta: Bulan Bintan, 2011), 47. 
gate for ijtihäd in Islamic theology discourse. In principal, Islamic theology must be accordance with modern science and otherwise, modern science should be in line with Islamic theology. ${ }^{21}$

As a universal and trans-nation religion, Islam came to Indonesia with peace tradition and was addressed by Islamic preachers (Muballig) who have good personality and plural scientific paradigm, so they could acculturate with local culture in Indonesia. This tradition of disseminating Islamic teachings has progressed significantly as Islamic school (Pesantren) in Java and Madura island was improving. The schools followed learning model which Prophet Muhammad ever practiced, i.e. halaqah system (small group model) in which sorogan and bandongan were included ${ }^{22}$

In this modern world, a narrow learning tradition and Islamic knowledge are not enough since the advanced progress of knowledge and technology could not be rejected with inflexible, exclusive, and group-based Islamic theology. However, we need universal, flexible, and simple Islamic theology. In this circumstance, recent paradigm of Islamic theology should have multi faces, not monolithic or exclusive. ${ }^{23}$ Islamic theology as a knowledge that describe relation between God and mankind has to pay attention on relation amongst people. It is not only understood as pure God discourse, faith, credo, and ultimate concern, but also it should be viewed as men problem on historical-cultural aspects. ${ }^{24}$

${ }^{21}$ Ibid., 53-55.

${ }^{22}$ http://mui-

sulsel.org $/$ index.php?option $=$ com_content\&view $=$ article\&id $=132$ :sejarahawal-penggunaan-metode-halaqah\&catid $=69$ :drs-h-waspada-santing-msosimhi\&Itemid $=187$

${ }^{23}$ Alwi Shihab, Islam Inklusif; Menuju Sikap Terbuka dalam Beragama, (Bandung: Mizan, 1999), 178; M. Amin Abdullah, Desain Pengembangan Akademik IAIN Menuju UIN Sunan Kalijaga: Dari Pola Pendekatan Dikotomisatomistik Kearah Integrative-interdisiplinary, (Paper presented at Seminar 21 Pascasarjana IAIN Sunan Kalijaga 16 March 2004), 7.

${ }^{24} \mathrm{M}$ Amin Abdullah, "Rekonstruksi Metodologi Studi Agama", in Ahmad Baidowi et al. (eds.), Rekonstruksi Metodologi Ilmu-ilmu Keislaman, (Yogyakarta: Suka Press, 2003), 4-5. 
In historical-cultural study, Islamic theology teachings as reality of people life have some aspects that closely relating to varied kind of people sakes in the world. It is often camouflaged under Islamic values which make scientist and religionist difficult to differentiate between fundamental aspect of Islamic theology and its cover. The historical-cultural problem challenges religionists to face new problems, meanwhile Islamic theology tends to be rigid, inflexible, and back to old time. Whereas, mankind keep living to future in which old tradition cannot bear it. ${ }^{25}$

The assembly of two interests of Islamic theology with historical-cultural interest is not easy to be disaggregated and purified for the substantial aspect from the other aspects, but non- religious/theology interest often restrain Islamic theology interest. Normative aspect of Islam relates closely to historicalcultural aspect. If we are no careful and smart in differentiating them, it will be difficult to differentiate original theology norm and fake one. In the area of science study, the scientist are still easy to differentiate pure science interest and applied sciences, but religionist or religion scholars often have difficulty in determining theology and non-theology area. ${ }^{26}$

On the same case, Muhammad Iqbal (1877-1938) in his book The Reconstruction of Religious Thought in Islam addresses the importance of plural Islamic theology. It states that Islamic teachings was revealed to prophet Muhammad saw to reflect tradition aspects, interest and his people's strength, but it does not mean that Islam is for mankind in certain group. Islamic teachings are meant to gather all groups and plural society. ${ }^{27}$

Islamic teachings in theology brought by Prophet Muhammad was to answer actual problems faced by mankind in giving inclusive and flexible breakthrough. Prophet Muhammad had given clear description how Islamic theology has dialogue

25Ibid., 5.

26Ibid.

${ }^{27}$ Djohan Effendi, "Islam di antara Teks dan Konteks" in Annual Conference on Islamic Studies (ACIS-10), Direktorat Pendidikan Tinggi Islam Ditjen Pendidikan Islam, Kementerian Agama RI, in Banjarmasin, 1 - 4 November 2010, 6. 
with historical-cultural reality as inevitability which cannot be made uniform between one region with other regions or between countries. M Amin Abdullah stated that paradigm of plural Islamic theology, well known as post-dogmatic paradigm (study which surpass textual norms), is not new thing in Islamic tradition. Soon after prophet Muhammad passing away, caliph Umar ibnu al-Khaththab had laid foundations of plural Islamic theology study which guarantee pluralistic in giving opinions and understanding Islamic teachings based on the sake of people without staying away from its main message, e.g. denial of 'muallaf right in distributing alms and denial of soldiers' right in sharing ganima. ${ }^{28}$

The paradigm of plural Islamic theology is part of continuing sunna of prophet Muhammad which always care real interest of people, and sunna of caliph Umar which is able to read the main message of Islamic teachings taught by prophet Muhammad, i.e. effort to surpass rigid textual rules of Islamic teachings as Umar did in case of actual interest. Thus, Islamic theology study should carefully consider actual condition, not only actual condition in the era of Prophet Muhammad and old time. ${ }^{29}$ Understanding the text of Islamic teachings in plural way can make easy and dynamics in the progress of thought, insight, and behavior in religious life. Regarding this, religious people will be able to answer actual problems properly and dynamically. In understanding the text of Islamic teachings, Djohan Effendi explained that text din not emerge in empty place and time, but text speaks and is understood, interpreted, and studied from time to time, from one place to others. Islam as theology is also born in dynamic and competitive clash of life, even in dynamic political conflict. For this reason, manifestation of understanding Islamic theology from original text or source (The Qur'an and Sunna) in Muslim people life is colorful. ${ }^{30}$

The explanation of Djohan Effendi gives insight that Islamic theology study requires wide knowledge and inter-connection between science and religion, between religion and religious

${ }^{28} \mathrm{Ibid}$.

${ }^{29}$ Ibid.

${ }^{30}$ Ibid. 
study so that Islamic theology can absorb and accommodate recent condition. Studying the works of Muslim scholars from past time, we should analyze conditions which emerge paradigm of Islamic theology. It is aimed at understanding and differentiating fundamental aspect of Islamic theology and historical-cultural aspects which have effect on Islamic theology.

If Islamic theology study can provide ideological and nontendentious scientific discourse then idealism in building plural tradition of religious life will come true sincerely, called pluralisme de jure. However, if we do not start with flexible and simple paradigm of Islamic theology then it will emerge unreal discourse and religious behavior, i.e. unreal tradition of plural life or called pluralisme de facto. This kind of tradition was experienced by religious people in Indonesia, especially in new order era. Religious people seemed to be harmonious but in fact they did not know one another and have mutual understanding amongst them. When reform era came with its transparency, old problems like suspicious come to the surface and it causes religious conflict in several places. The conflict is actually not on behalf of religion but it refers to non-religion problems. The non-religion problems are forced to be religion problems which lead to religious conflict. Religious conflicts like in Ambon and Maluku were valuable and important lesson where non-religions problems influence and destroy the foundation of inter-religion relationship. ${ }^{31}$

The conflict has been resolved via Malino treaty I and II in 2002-2003 represented by public figure from Islam and Christian. A special thing in conflict resolution of religion anarchy in Maluku is that representation and revitalization of local wisdom such as gandong between the villages in Maluku to have each other as brother or sister. ${ }^{32}$

Frank Whaling 33 viewed that conflict in Ambon was affected by implementation of faith or interpretation of faith, and also

${ }^{31}$ Result of field observation in Ambon on 17-18 November 2015.

32Wasisto RaharjoJati, "Kearifan Lokal sebagai Resolusi Konflik Keagamaan”, Journal Walisongo. Ac.id, Volume 21, No, 2, November 2013, 395; visit journal.walisongo.ac.id/index.php/wali/article/.../108, accessed at 30 October 2015.

${ }^{33}$ Frank Whaling, "Pendekatan Teologis", in Connolly (eds.), Aneka Pendekatan, 31. 
social-political, economic and cultural aspects. Religious conflict in Ambon or Maluku reflects the pattern of partly plural religious life, for not saying that is pattern of unreal religious life. ${ }^{34}$ Condition in Ambon is a reflection of pattern of religious life in the form of pluralisme de facto. Critics must be addressed for this pluralism since it still contains paradigm of exclusive theology which claim the truth belongs to only one group and the others must be in wrong way.

In history, paradigm of exclusive Islamic theology had been a part of early progress of theology in Muslim people affected by non-religion factors, and then varied groups exist where most of their members blame one another. Further, different Islamic thought in theology have legalized killing members of different group. This ironic condition occurred in Muslim people. This conflict exists in the name of theology or religion and nonreligion aspects until nowadays, e.g. civil war in Middle East. One of the crucial problems which spread revolution in Middle East is gap in economic and human resources.

Historically, when countries in Asia and Africa had got their independence, they could not manage their natural resources independently. Meanwhile, west countries could manage but lack of natural resources. The problem of human resources influenced political system in Middle East, i.e. democracy was partly practiced. One of the popular problems was gap in economic between ruled government officers (and their family) and ordinary people. This problem triggered non-stop political revolution in Middle East. Nevertheless, Islamic theology also played roles in creating conflict in the form of radical groups such as Wahhabi, Ikhwan al-Muslimeen, al-Gama'a Islamiyya, alQaeda. ${ }^{35}$ Al-Qaeda is one of the radical groups which plan to establish Khiläfah Islamiya and "drive away non-Muslim from Islamic countries" in Southeast Asia. South Thailand and Philippine in southern area were two operation areas of $\mathrm{Al}$ Qaeda where Muslim people are minority and being marginalized in both countries. Al-Qaeda did not have difficulty

${ }^{34}$ Ibid.

${ }^{35}$ Result of observation on Seminar in IAIN Bengkulu. The speaker was Indonesia's ambassador for Yordaniah, Teguh Wardoyo, 27 April 2015. 
in recruiting followers to be involved in mission since many alumnus of $\mathrm{Al}$-Qaeda were already there. ${ }^{36}$ Therefore, gap in economic, social, politic, and education also contributed to the emergence of radicalism or fundamentalism in religion.

Political conflict in Syria began on March 2011. Graffiti on school wall made by 15 students (age 9-15) in small town namely Deraa, in southeast area of Syria next to Jordan marked starting of the war. The children were possibly inspired by conflict in Tunisia which force Tunisia's president (Zain al-Abidin bin Ali) to step down on January 14, 2011 and conflict in Egypt which make Hosni Mubarak retreat from his presidential position. Graffiti on the wall was written As Shaab Yoreed Eskaat al-Nizami or the regime must step down. Syria polices were led by General Atef Najib, the cousin of president Baṣ al-Assād catched and jailed the children. As a consequence, people protested to release the children and asked for freedom. The armies were over reactive by shooting the people, 4 died. The armies' action triggered more protests and rebellion around Deraa to Latakia and Banyas in Mediterania shore or Middle Sea, Homs, Ar Rasta, Hama in Western Syria, and Dei esZor in Eastern Syria. ... at least 36.000 killed, 28.000 were missing, and over 100.000 were refugees to several neighborhood countries. Regarding number of Syria's population, i.e. 22,5 million, the casualties are in high number. ${ }^{37}$

Conflict in Syria has caused many victims and refugees. It is a red note for the image of Islam in the world. This conflict indicates that non-religion factors are very dangerous if they meet with exclusive Islamic theology. This contradicts to paradigm of Islamic theology taught by prophet Muhammad saw. He taught inclusivity or pluralism by developing intimate brotherhood amongst Muslim, brotherhood amongst mankind, and brotherhood amongst people in Madina. Therefore, the awareness of religious people in that area is limited in religious life, rigid and petty. These shape a pattern of behavior which reflects similar ideas. Ideal pluralism in same religion and inter-

${ }^{36}$ As'ad Ali Said, Al-Qaeda: Tinjanan Sosial-Politik, Ideologi dan Sepake Terjangnya, (Jakarta: LP3ES, 2014), 196.

${ }^{37}$ Siti Muti'ah Setiawati, "Pergolakan Panjang Suriah: Masih Adakah Pan-Islamisme?”, Journal of CMES Volume V no. 1, July- December 2012 PUSAT STUDI TIMUR TENGAH FSSR UNS,5, https:/ / cmesuns.files.wordpress.com/2013/04/cmes-vol-5-no-1-edisi-juldes-2012.pdf, accessed on 30 October 2015 
religion could not be built sincerely, as a result if a conflict takes place then religion will not be a cure, otherwise it is a part of factor that worsened the civil war. Pan-Islamism movement which aims to unity Islamic countries then successfully established Islamic Organization Conference (Organisasi Konferensi Islam) in 1969. This organization failed to resolve civil war in Middle East. ${ }^{38}$

Analyzing the phenomena, M Amin Abdullah ever mentioned that, in fact, it is complicated to choose and differentiate religion and religious problems, normative religion problems and religious historical-cultural problems. Thus, when both problems could not be separated properly, religion as good life guidance and plural will play contrary roles.

Jihad movement and the establishment of Islamic countries through violence do not reflect the real paradigm of Islamic theology but this irresponsible way just name after faith or Islamic theology. Furthermore, it can be categorized as over action or extreme (al-tatarruf) which cause victims in history. One of the examples of extreme actions was case of Ali bin Abi Talib as a victim of exclusive Islamic theology. As explained, this paradigm is claimed as the truth one and the others are wrong. Abdurrahman bin Muljām is the actor of exclusive paradigm. ${ }^{39}$

\section{Paradigm of Plural Islamic Theology in NKRI}

The emergence of fanatic action and truth claim is not only caused by exclusive paradigm but also by over commitment in religion. Resolving this extreme paradigm, moderate paradigm which promotes balance between "commitment" and "transparency" must be developed. ${ }^{40}$ This resolution is quite important to face this era especially in Indonesia where religion conflict like Ambon case easily comes around. The conflict is

\section{${ }^{38} \mathrm{Ibid}$.}

${ }^{39}$ Muchlis M. Hanafi, "Konsep al-Washatiyyah dalam Islam", HARMONI: Journal Multicultural \& Multi religious Vol. VIII No. 32 (October - December 2009), 47.

${ }^{40}$ Muhammad Wahyuni Nafis, "Refrensi Historisbagi Dialog Antaragama", in Komaruddin Hidayat and Ahmad Gaus AF (eds.), Passing Over: Melintasi Batas Agama, (Jakarta: Gramedia dan Paramadina, 2001), 95. 
caused by many interests that are not under plural and sincere scientific paradigm. ${ }^{41}$

Sincere harmonious and corporation in religious life and social-cultural are expected to be achieved properly by developing plural Islamic theology or pluralisme de jure, not unreal religious harmony (having religious) or pluralisme de facto. General steps to develop paradigm of plural Islamic theology are: First, Muslim people need to develop sincere and plural Islamic theology paradigm by referring to basic values of progressive theology with productive scientific study (read: al-qiräah almutija). ${ }^{42}$ Second, Muslim people are required to read and research the other faith and theologies as a comparison to open better dialogue and corporation either in conceptual or practical level. ${ }^{43}$ Third, there is a need to develop plural paradigm which acknowledge existence of other theologies (alterite) equally and their difference, not in normative way. It means that we must respect to other religions theology. ${ }^{44}$ Fourth, paradigm of plural scientific as Emmanuel Levinas ${ }^{45}$ stated that Muslim people are invited to see scientific ethics as life phenomena in plural religious at any condition, not viewing from certain theology. On the other word, reality of religious people life in different theologies should be expressed that the existence of other religion theology is valuable and respectful. We do so not to just respect but for the existence of plural religion theology which put their existing theology or other religions at any condition. This concept in Islamic study is known as 'urf, i.e. respecting good tradition as it is. ${ }^{46}$

Practical steps to implement paradigm of plural Islamic theology are: First, Muslim people need to develop insight on Islamic theology integrating to plural life of society and apostate

${ }^{41} \mathrm{~A}$ Mukti Ali, Ilmu Perbandingan Agama di Indonesia, (Bandung: Mizan, 1998).

42Jawa Pos, Sunday 29 August 2004, 4.

${ }^{43}$ Abdullah, Studi Agama, 65.

${ }^{44}$ Emmanuel Levinas/Professor at Universitas Paris IV (Sorbonne), Franz Magnis-Suseno, 12 Tokoh Etika Abad ke-20, (Yogyakarta: Kanisius, 2000), 92.

${ }^{45}$ Ibid.

46Abdul Wahab Khallaf, 'Ilm Usūl Fiqh, (Kairo: Dār al-Qalam, 1978), 90. 
doctrine should not be accepted. As long as the doctrine exists in each religion theology, pluralism in religion will never happen either in conceptual or practical level. Second, there is a need to develop just one kind of scientific paradigm, legal or forbidden, Muslim or not, but transparency is important to acknowledge the difference in religious life so that the terminology of Muslim-heathen is no longer relevant used in the discourse of plural Islamic theology. ${ }^{47}$ Third, the religious people, especially Muslim people in Indonesia, need to build pattern of religious life which create conducive atmosphere. It can be done by totally respecting others, include soul, thinking, faith, and religion faith, not only include outside aspect but also soul and religion faith. All of these must be planted sincerely to live together in diversity. 48

Paradigm of plural Islamic theology is relevant in Indonesia. It relates to principle no. 1 of Pancasila (5 principles of Indonesia), believing in one God. Pancasila is basic and leading principle for national and state. Therefore, Islamic theology in Indonesia must be in line and related to the reality of plural life in Indonesia. All formulated regulations or policies must reflect the $1^{\text {st }}$ principle of Pancasila. Furthermore, since the $1^{\text {st }}$ principle exists, a special department which manages religions is needed. Indonesian independence preparatory committee (PPKI) approved the idea of establishing religion department (now it is Ministry of Religion) in Indonesia. One of its functions is to give "religion enlighten and counseling" and "follow and look for any cases relating to religion and religious".49

In Abdurrahman Wahid's view, the construction of interreligious life must be laid on grounding Islamic theology paradigm and relevant to plural condition, i.e. building up

${ }^{47}$ Mohammad Damami, Kepercayaan terhadap Tuban Yang Maha Esa pada Periode 1973-1983: Sebuah Sumangan Pemahaman tentang Legislasi Konstitusional dalam Konteks Pluralitas Keberagamaan di Indonesia, (Jakarta: Kementerian Agama RI, 2011), 259.

${ }^{48}$ Nasrullah Ali Fauzi, "Abdul Mukti Ali”, in Ulumul Qur'an, No 3. Vol 5. 1995, 30; KautsarAzhari Noor, Tasawuf Parennial; Kearifan kritis Kaum Sufi, (Jakarta: Serambi Ilmu Semesta, 2002), 71; A Mukti Ali, Ilmu Perbandingan Agama, (Yogyakarta: Yayasan NIDA, 1970), 32-33.

${ }^{49}$ Damami, Kepercayaan, 216-217. 
relationship and corporation between religious people properly and sincerely. To initiate this kind of relationship and corporation, we need to build paradigm of Islamic theology which functions as welfare vehicle for universe (rabmatan li al'alamin). The term is interesting since it defines rabmat as welfare not mercy. For Wahid, mercy is abstract but welfare guarantee a system of life in nationality and statehood which is able to realize welfare. Wahid viewed Islam as welfare theology since it is ethical and social-oriented. Therefore, the real paradigm of plural Islamic theology is a theology which creates balance in relation with God and amongst mankind. It can place good deeds as a weigher to measure the level of someone's faith (read: Q.s. al-Baqarah [2]:177). Focusing on the existence of mankind (Q.s. al-Baqarah [2]:32) then main message of the real Islamic theology is to defend and protect the existence of mankind as human right. ${ }^{50}$

In national life, NKRI can be a tool for the goal of Islamic theology; the shape of state is no longer important. Moreover, in state's basic principle (Pancasila), contains the same ideal of social justice with the principles of Islamic theology that is very concerned about human existence. According to Wahid, Indonesia has gone beyond the dichotomy of integration (statereligion) and separation (state without religion). Paradigm of Islamic theology developed by Wahid is the paradigm of Islam as a theology of social ethics which can shape public civility for the sake of Civility State. In this case, the paradigm of plural Islamic theology used and relied upon by the founding fathers by making the values of Islamic theology as the ethical foundation for the basic of state. ${ }^{51}$

\section{Conclusion}

Paradigm of plural theology studies will be able to reveal good pattern of inter-religion relationship using the approach of Scillebeeckx Edward. Paradigm of Islamic theology studies here

\footnotetext{
${ }^{50}$ Syaiful Arif, Teologi Kebangsaan Gus Dur, http://www.nu.or.id/a,publicm,dinamic-s,detail-ids,4-id,49235-lang,id-c,kolom-

t,Teologi+Kebangsaan+Gus+Dur-.phpx, accessed on 29 October 2015.

${ }^{51}$ Ibid.
} 
want to build a scientific paradigm of Islamic theology with the aim of establishing a pattern of genuine inter-religion relationship using Edward Scillebeeckx approach to build pattern of religious life and cooperation colored by pluralisme de jure, not pluralisme de facto. With the development of plural Islamic theology, the scientific paradigm of Islamic theology of Muslims would be open, flexible and not rigid. In religious life, scientific paradigm of theology that will give birth to a pattern of religious life and the nation in diversity sincerely or pluralism de jure, i.e. being religious, not unreal inter-religion pattern of life in pluralism or pluralisme de facto, i.e. having religious.

Paradigm of plural Islamic theology is needed to build a plural system of national and state life, which is expected by paradigm of Islamic theology, will be able to encourage the birth of life pattern and interfaith cooperation properly and sincerely. At the same time, it will make pressure on all potentials which lead to religious conflict. If scientific paradigm acquired and built is plural, then it would be very supportive for the birth of a pattern of plural religious and national life as well. $W a$ al-Lāh a'läm bi al-sawāb.

\section{References}

Abdullah, M. Amin et al, (eds.). Antologi Studi Islam. Yogyakarta: DIP PTA IAIN Sunan Kalijaga, 2000.

Abdullah, M. Amin. Studi Agama; Normativitas dan Historisitas. Yogyakarta: PustakaPelajar, 1996.

-----------. "Design Pengembangan Akademik IAIN Menuju UIN Sunan Kalijaga: Dari Pola Pendekatan Dikotomisatomistik Kearah Integrative-interdisiplinary", Paper on Seminar 21 Pascasarjana IAIN Sunan Kalijaga (16 Maret 2004).

Ali, A Mukti. Ilmu Perbandingan Agama. Yogyakarta: Yayasan NIDA, 1970.

1998.

Amstrong, Karen. Sejarah Tuban, translated by Zaimul Am. Bandung: Mizan, 2001. 
Arif, Syaiful. http://www.nu.or.id/a,public-m,dinamic-s,detailids,4-id,49235-lang,id-c,kolom-t,Teologi+Kebangsaan+Gus +Dur-.phpx, (accessed onn 29 October 2015).

Athaillah, A. Rasid Rida': Konsep Teologi Rasional dalam Tafsir alManar. Jakarta: Erlangga, 2006.

Baidowi, Ahmad et al. (eds.). Rekonstruksi Metodologi Ilmu-ilmu Keislaman. Yogyakarta: Suka Press, 2003.

Barton, Greg. Gagasan Islam Liberal di Indonesia; Pemikiran NeoModernisme Nurcholish Madjid, Djohan Efendi, Ahmad Wabib, dan Abdurrabman Wabid, translated by Nanang Tahqiq. Jakarta: Pramadina, Pustaka Antara, and The Ford Foundation, 1999.

Connolly, Peter (ed). Aneka Pendekatan Studi Agama, translated. Imam Khoiri. Yogyakarta: LKiS, 199.

Damami, Mohammad. Kepercayaan terhadap Tuhan Yang Maha Esa pada Periode 1973-1983: Sebuah Sumangan Pemahaman tentang Legislasi Konstitusional dalam Konteks Pluralitas Keberagamaan di Indonesia. Jakarta: Kementerian Agama RI, 2011.

Effendi, Djohan. "Islam di antara Teks dan Konteks" in Annual Conference on Islamic Studies (ACIS-10), Direktorat Pendidikan Tinggi Islam Ditjen Pendidikan Islam, Kementerian Agama RI, di Banjarmasin (1 - 4 November 2010).

Fauzi, Nasrullah Ali. "Abdul Mukti Ali”, in Ulumul Qur'an, Vol 5. No 3. (1995).

Hanafi, Muchlis M. "Konsep al-Washatiyyah dalam Islam", HARMONI: Jurnal Multikultural \& Multireligius Vol. VIII No. 32 (Okcober - December 2009).

Hidayat, Komaruddin, dan Ahmad Gaus AF (ed.). Passing Over Melintasi Batas Agama. Jakarta: Gramedia \& Paramadina, 2001.

http:/ / mui-sulsel.org/index.php?option $=$ com content\&view $=$ article\&id=132:sejarah-awal-penggunaan-metode-halaqah \&catid=69:drs-h-waspada-santing-msosi-mhi\&Itemid $=187$. https://cmesuns.files.wordpress.com/2013/04/cmes-vol-5-no1-edisi-jul-des-2012.pdf, (accessed on 30 Oktober 2015). Jati, Wasisto Raharjo. "Kearifan Lokal sebagai Resolusi Konflik Keagamaan”, Journal W alisongo. Ac.id, Volume 21, Nomor 2, (November 2013). 
JawaPos, (Minggu, 29 Agustus 2004).

Journal.walisongo.ac.id/index.php/wali/article/.../108, (accessed on 30 October 2015).

Khallaf, Abdul Wahab. Ilm Usūl Fiqh. Kairo: Dar al-Qalam, 1978.

Kurzman, Charles (ed.). Wacana Islam Liberal: Pemikiran Islam Kontemporer tentang Isu-Isu Global, tranlated by Bahrul Ulum. Jakarta: Paramadina, 2001.

Lapidus, Ira M. Sejarah Sosial Ummat Islam, translated by Ghufron

A Mas'adi. Jakarta: PT Raja Grafindo Persada, 1999.

Magnis-Suseno, Franz. 12 Tokoh Etika Abad ke-20. Yogyakarta: Kanisius, 2000.

Marjani, Gustiana Isya."Multikulturalisme dan Pendidikan: Relevansi Pendidikan dalam Membangun Wacana Multikulturalisme di Indonesia", in Paper ACIS Diktis Depag RI, (2009)

Muhtarom, Zaini et al (editorial). Ilmu Perbandingan Agama Di Indonesia (Beberapa Permasalahan). Jakarta: INIS, 1990.

Muzani, Saiful (ed.). Islam Rasional: Gagasan dan Pemikiran Prof. Dr. Harun Nasution. Bandung: Mizan, 1995.

Nasution, Harun. Pembaruan dalam Islam: Sejarah Pemikiran dan Gerakan. Jakarta: Bulan Bintang, 2011.

Noor, Kautsar Azhari. Tasawnf Parennial; Kearifan kritis Kaum Sufi. Jakarta: Serambi Ilmu Semesta, 2002.

Said, As'ad Ali. Al-Qaeda: Tinjanan Sosial-Politik, Ideologi dan Sepake Terjangnya, Jakarta: LP3ES, 2014.

Setiawati, Siti Muti'ah. "Pergolakan Panjang Suriah: Masih Adakah Pan-Islamisme?", Jurnal CMES 5, No. 1, (JuliDesember 2012) Pusat Studi Timur Tengah FSSR UNS.

Shihab, Alwi. Islam Inklusif; Menuju Sikap Terbuka dalam Beragama. Bandung: Mizan, 1999.

TIM Yayasan Paramadina. Al-Ghazali tentang Ilmu Kalam. Jakarta: Yayasan Wakaf Paramadina, 1995.

UUD 1945 dan Amandemennya, Surakarta: Al-Hikmah. 